\title{
(Post)Modern Apocrypha as an Epiphany of Sense (ON THE BASIS OF BULGARIAN LITERARY Biblical Paraphrases)
}

The concept of "apocrypha" is quite exploited in the humanities today. It is defined and specified in many ways but nevertheless remains imprecise and ambiguous ${ }^{1}$. My intention is not to give some clarity in this regard, but to show a new possible perspective to the subject by focusing on the subject of so called "contemporary apocrypha", so that the ambiguousness could be perceived as a premise for a hermeneutical approach. Therefore, I would like to show the literary reinterpretation of the Bible in a different light, and thus to propose a new concept of "modern apocrypha" which refers to the modernity ${ }^{2}$. In my

\footnotetext{
${ }^{1}$ Further reading cf.: M. STARowiEYSKI, Wstęp, [in:] Apokryfy Nowego Testamentu, vol. I.1, Ewangelie apokryficzne, ed. M. Starowieyski, Kraków 2003, p. 19-84; M. ADAMCZYK, Apokryf, [in:] Stownik literatury staropolskiej, ed. T. MichaŁowska, Wrocław 2002, p. 46-55; D. SzAjnerT, Mutacje apokryfu, [in:] Genologia dzisiaj, ed. W. Bolecki, I. Opacki, Warszawa 2000, p. 137-159; B. BedNAREK, „Apokryf”. Próba kategoryzacji pojęcia, [in:] Nie-złota legenda. Kanoniczność i apokryficzność w kulturze, ed. J. EichstaedT, K. PiątKowski, Ożarów 2003, p. 35-40. As the paper gives examples from Bulgarian literature, it should be noted that there are some important works on the apocrypha in Bulgarian studies, mainly regarding the Medieval period (e.g. the studies of Donka Petkanova, Anisava Miltenova, Florentina Badalanova-Geller, or Georgi Minczew; also: K. Gecheva, Bibliography on the Pseudepigrapha Studies in Bulgaria, http://www.marquette.edu/maqom/gecheva.html [17 X 2014]). It is not necessary, however, to give more detailed information in this regard, not only because the case with the Old Bulgarian (or Old Slavonic) apocrypha is not a subject of my interest here, but also because this kind of apocrypha has developed in a specific cultural situation, different than the ancient (or early Christian) one, so the theoretical reflection refers to the specific matters. For more: A. Naumow, Apokryfy w systemie literatury cerkiewnosłowiańskiej, Wrocław 1976. The concept of "contemporary apocrypha" has not been studied in Bulgarian studies. It is used in a typical context which refers to the history of literature. Cf. e.g.: Д. НАКОв, Съвременните апокрифи - „Между пустинята и живота" и „Последното изкушение” - привличания и отттасквания, Л 7, 2010, p. 432-447.

${ }^{2}$ The double term "(Post)Modern apocrypha", mentioned in the title of the paper, implies the ambiguity of the concept of modernity, which may refer both to the modernism and the postmodernism, and even to the post-postmodernism. Recently, it has been pointed out that the modernity has a wider meaning, so it covers not only the modern movement begun in the late $19^{\text {th }}$ and $i t s 20^{\text {th }}$ century apogee, but also the new phenomenon from the early $21^{\text {st }}$ century. Therefore, the designation "(post)modern" both remind the traditional distinction, and signify the ambiguity of the reference mark. If the distinction matters in particular (i.e. if the modernity is perceived as a wider description of the epoch fundamentally different than pre-modern period), it will be marked by the usage of the term "modern apocrypha".
} 
terms, regardless the terminological ambiguity, the modern apocrypha is a text of the modern culture, and because of that - a source for the further studies on the epoch $^{3}$.

Basically, the concept of "apocrypha" has two meanings: biblical and colloquial. The first is connected with ecclesiastical usage and is defined in opposition to the Canon of Scripture, i.e. it concerns texts which have not been acknowledged as written down under the inspiration of the Holy Spirit. The second shows a work (on a biblical topic) which is unauthentic but styled in such a way as to fake the original and to function especially in common thinking and in literary studies and recently even in popular culture. As a consequence apocrypha do not represent a separate literary genre but remain simply a loose and yet inspiring biblical and literary category.

I shall skip here the well-known history of this concept in the religious (institutional) context ${ }^{4}$. What I would like to underline as a fundamental for my approach is that apocrypha have an essential duality. It is not only secondary in the sense of the contents in regards to their source, but it is also ambiguous from doctrine's point of view. Even in the affirmative attitude towards the canon there is a specific usurpation. Such texts, suggesting the necessity of supplementing or better reflecting, as a matter of fact, fake it. Finally the ambivalence of the apocryphal message is best expressed in the status of a border event: between orthodoxy and heterodoxy, centre and periphery, the elite and common people, tradition and innovation and even between different genres of narration ${ }^{5}$.

In the case of apocrypha, which at this point I claim "contemporary", this fundamental duality becomes hidden, it receives a new dimension. It functions in a completely changed context, which on the one hand is connected with the existence of modern autonomization of arts as a space of human (auto)creation and on the other hand with a change in the status of the Holy Scripture. The Bible is subject to a division into a religious and a cultural text. In this way in the modern epoch there are two - at first sight contradictory - forms of its reading ${ }^{6}$. The enlightenmental doubt in the authority of the canon of the inspired texts (and the Church as an institution) ultimately leads to a denial of the need of a normative

\footnotetext{
${ }^{3}$ On this topic see see my text in Bulgarian cf.: Е. ДжЕВИЕцКА, Модернистичните парафрази на библейския сюжет като извор за българската история на идеите (2013), http://bgmodernism. com/our_modernism/Ewelina_Drzewiecka [17 X 2014]. This paper, however, is devoted entirely to the new concept of apocrypha from the theoretical point of view, whereas the Bulgarian one focuses rather on the example of its usage. The literary material given in both of them has been presented in my other studies, which will be marked further in the notes. The main idea of modern apocrypha as an epiphany of sense was mentioned as well in: E. Drzewiecka, Metamorfozy Judasza. Autorskie parafrazy biblijne jako świadectwo przemian kulturowych (na przykładzie literatury bułgarskiej), PF.L 3(6), 2013, p. 143-163.

${ }^{4}$ Polish introduction to this subject: M. Starowieyski, op. cit.; R. Rubinkiewicz, Wprowadzenie do apokryfów Starego Testamentu, Lublin 1987.

${ }^{5}$ M. ZowCzaK, Apokryf jako próba wiary, [in:] Nie-złota legenda..., p. 45-75.

${ }^{6}$ B. Krzyżaniak, Biblia i antropologia. Spotkania niedokończone, Poznań 2004, p. 7-20.
} 
centre as itself. In this sense the unusual popularity, which can be seen nowadays in Western culture, of the disinherited concept of apocrypha observed in postmodern conditions - creates a paradox - probably showing the presence of a specific hidden nostalgia for the lost world.

In this context Magdalena Zowczak understands the apocrypha as a specific "trial of faith" . In a similar perspective will be situated the concept presented here. I would like to give arguments for the existence of the concept of "apocrypha" not in the theory of literature but rather in hermeneutics as a field which unites all reflections of human thought. I would like to suggest a hermeneutic passage from "apocrypha as a literary mystification" ("literary apocrypha"), i.e. a concept often applied in literary studies, to "apocrypha as an epiphany of sense", i.e. a concept which can be useful in cultural studies and in the history of ideas. I would like to show apocrypha as an individual interpretation of the canon rather than a minority one and at the same time to empower it as evidence of the research of sense and by that to get a reverse relation with its original definition.

Contemporary apocrypha as mystified biblical stories - in regards to their repetitiveness but also (auto)ironic suspension - appears to be camouflage, an unengaging game with the readers. In the light of postsecular theory, however, such a text is not just a literary fiction but also a theological message. As Agata Bielik-Robson argues, referring to Walter Benjamin's metaphor about the puppet and the little hunchback ${ }^{8}$, at the bottom of each, even the most secular (secularized), worldview there is a hidden choice of a theological nature, and as such she calls this undisclosed model of thinking "crypto-theology". In this sense (literary) apocrypha turn out to hide an individual's (author's) axiological horizon.

As an adaptation of the biblical plot contemporary apocrypha seem to be a stylization according to Stanisław Balbus's paradigm, i.e. it functions in a twofold relation with tradition, as a reinterpretation of the past and as an interference within the present ${ }^{10}$. Although the borrowed element is put in a completely new context, it shows in fact a (meaningful) cultural distance, and thus establishes a personal conversation with the Biblical source in a wide hermeneutical perspective. As a result, it becomes a method but also an expression of interpretation of the (Judeo-)Christian tradition ${ }^{11}$. What is important is that the change, typical of the stylization, of the primary function of the adapted forms in the case of contempo-

\footnotetext{
${ }^{7}$ M. ZowCZAK, op. cit., p. 59-61.

${ }^{8}$ Cf. W. Benjamin, Theses on the philosophy of history, [in:] IDEm, Illuminations, ed. H. Arendt, trans. H. ZoHN, New York 1968, p. 253.

${ }^{9}$ A. Bielik-Robson, „Na pustyni”. Kryptoteologie późnej nowoczesności, Kraków 2008, p. 7-10.

${ }^{10}$ S. Balbus, Między stylami, Kraków 1996, p. 53-71. It should be underlined that usage of Balbus's concept here is of a predominately heuristical character. It has not been applied in full, i.e. the article does not undertake detailed differentiations of the concepts and directs to its hermeneutical potential. ${ }^{11}$ Although in Balbus's view the stylization neither doubts, nor rejects the model but initiates and mystifies semiotic impulses (S. BALBUs, op. cit., p. 66), from a perspective of the history of ideas it can be concluded that it always leads to a relation towards the source.
} 
rary apocrypha takes place not only with reference to the opposition "orthodoxyheterodoxy" but also "religious text-artistic text". In this way it presents two double heterogenic and not reducible to each other contextual systems, so the seeking sense is a result of their conflict. The duality is expressed with regards to not only the message but also the epistemological order.

The consequences of the essential duality of the apocrypha manifest themselves in the suspension of its contemporary version at the crossroads of heterogenic perspectives. It functions in two different orders, separated at the beginning of modern times, i.e. that of the aesthetic and the religious. So it potentially amplifies two styles of reception: allegorical (or symbolic) and mimetic (or mythic) ${ }^{12}$, actualized respectively by literary critics and by theologians (representatives of the Church). It is a work of art but referring to the biblical canon, aspires to create a "religious" (crypto-theological) message, which approves or rejects the paraphrased contents. The modern apocrypha takes a different place in the text hierarchy, because its artistry is treated like a new form of expression hence a pretext but also a specific alibi for the author who intends to make a religious transgression. As a result its intertextuality is mainly revealed in the meaning of mediation ${ }^{13}$.

In this way the (post)modern apocrypha are evidence of sense seeking. From a hermeneutic perspective, as defined by Hans-Georg Gadamer ${ }^{14}$ and Paul Ricoeur ${ }^{15}$ it is an act of the existential dimension; according to Hannah Arendt, it is an expression par excellence of the dynamic activity of thinking, related with the experience of the difference encrypted in the human condition, dissonance and hence duality ${ }^{16}$. As the process of finding meaning is performed through the act of accepting two points of view at the same time, so can the literary text have the function of a mirror for the thinking reader not only of his own reflection but also of the inner dialogue of the author. If literature not only "gives rise to thought" but also is its testimony, then contemporary apocrypha appear to be a double mirror of (both reader's and writer's ) reading of the biblical canon ${ }^{17}$. Expressing the philosophy of suspicion, it is born of the feeling of its insufficiency. However there is no ambition to catch up with the canon or to create a mythic fiction ${ }^{18}$, which demands unconditional belief in the text, referring to a mutual worldview horizon.

\footnotetext{
${ }^{12}$ M. GŁowı́́ski, Dzieło wobec odbiorcy. Szkice z komunikacji literackiej, Kraków 1998, p. 144-147. It can be related with the parabolic or mimetic fiction in Głowiński’s terms (ibidem, p. 212-216).

${ }^{13}$ This aspect is in a wide sense underlined by Ryszard Nycz, Intertekstualność i jej zakresy: teksty, gatunki, światy, [in:] IDEM, Tekstowy świat, Kraków 2000, p. 79-109.

${ }^{14}$ H.-G. Gadamer, Truth and Method, trans. J. Weinsheimer, D. G. Marshall, New York 2004.

15 P. Ricoeur, The Conflict of Interpretations. Essays in Hermeneutics, ed. D. IHDE, trans. W. DoMINGO et al., Evanston 1974.

${ }^{16}$ H. Arendt, The Life of the Mind. Volume One. Thinking, Orlando 1978, p. 241-280. Cf. M. MiCHALSKI, Dyskurs, apokryf, parabola. Strategie filozofowania w prozie wspótczesnej, Gdańsk 2003, p. 27-35.

${ }^{17}$ M. Michalski, op. cit., p. 173.

${ }^{18}$ M. GŁOWIŃsKI, op. cit., p. 210-212.
} 
Compared to ancient apocrypha, it is "degraded", closed into the literary world". The reflection of reality becomes mediated by the reflection of cultural themes; the key is the tension that rises as a result of reinterpretation between the meanings, i.e. between the fixed notion (the canon) and the author's vision ${ }^{20}$.

Text referring to the Bible in (post)modern conditions appears to be doubly ambivalent but also with double meaning as it actualizes not only the understanding (sense) but also the knowing (truth), and thus it confirms the union between the epistemological and axiological plan of human existence. Reading the apocrypha means an articulation of identity, which according to Charles Taylor means articulation of values as well ${ }^{21}$, and in this sense it must mean an actualization of the opposition between the orthodoxy (i.e. approving the source, Eastern Christianity) and the heterodoxy (i.e. rejecting the source, heresy). Modern apocrypha can be understood as a text for the initiated, both in religious and aesthetic sense, but also in philosophical one.

In this way the most appropriate term appears to be paraphrase, although not in its strictly literary sense, telling about the basic keeping of the source message ${ }^{22}$, but in this filtered by the philosophical look, pointing at a repetition in the frame of the critical distance, i.e. in the new context and with a change $e^{23}$. Predefined in such a way by Agata Bielik-Robson - based on the theory of parody by Linda Hutcheon ${ }^{24}$ - the concept underscores the fact that the subject is an evidence of author's interpretation ${ }^{25}$. Modern apocrypha is something more than a camouflage to a fiddly literary game, which makes out a mystification; it is a hermeneutical work - very important in the field of the history of ideas - because it acts as an individual (minority) interpretation of the canon, revealing more epistemological possibilities $^{26}$.

\footnotetext{
${ }^{19}$ M. Michalski, op. cit., p. 164-166. In its transpositionality it has an ambiguous (dynamic), but also autoironic sense. Ibidem, p. 161-174.

${ }^{20}$ Ibidem, p. 44-166. Coming back to Balbus's conception, it can be conceded that the (post)modern apocrypha as a stylization enable a specific ingression of the past tense; being a trial to giving a present perfect status to what is situated beyond the "living" tradition, it wakes and refreshes the historical continuation in new conditions. In effect it appears as a potential bracing natural "prosthesis" in critical moments of the culture of the update of the inheritance of the past - S. BALBUS, op. cit., p. 68-70, 430-431.

${ }^{21}$ CH. TAYlor, Sources of the Self. The Making of the Modern Identity, Cambridge 2001, p. 53-90.

${ }^{22}$ J. SŁawiński, Parafraza, [in:] Słownik terminów literackich, ed. IDEM, Wrocław 2000, p. 371.

${ }^{23}$ A. BIelik-Robson, Czy duchowość ponowoczesna jest możliwa? [in:] EAdem, Inna nowoczesność. Pytania o współczesna formułe duchowości, Kraków 2000, p 265-268

${ }^{24}$ L. Hutcheon, A Theory of Parody: The Teachings of Twentieth-Century Art Forms, ${ }^{1}$ London-New York 1985, ${ }^{2}$ Champaign 2001.

${ }_{25}$ The rejection of "parody" by Michalski too narrow a concept, as in its focus on critical attitude only (M. Michalski, Dyskurs, apokryf, parabola..., p. 167) it reveals on one hand a tight literary interpretation, maybe because of too fast reading of Hutcheon's theory, on the other hand - directly shows the fruitfulness of Bielik-Robson's philosophical apposition.

${ }^{26}$ M. ZowCZAK, op. cit., p. 47.
} 
I will show this potential on the basis of the Bulgarian literature and of those texts which paraphrase sensu stricto an evangelical story. Contemporary revisions of the Christian Good News appear to tell a lot about the condition of the (post) modern man who having lost his contact with the sacred/transcendental is forced to seek alternative ways of surviving in the state of (spiritual) alienation. In this sense apocrypha is a very expression of the so called heretical imperative, which according to Peter Berger is distinctive for the (post)modernity epoch state of the multiple choice. As this American sociologist underlines, the process of modernization (and secularization) - in regards to pluralization of institutions and opinions, and thus relativization of worldviews, effecting in losing fundamental certainty - has brought (potentially productive) passage from the world (of sense) of fate/destination to the world (of necessity) of the choice ${ }^{27}$.

As modern interest in the Holy Scripture is caused by the typical for the epoch critical, and even contesting attitude towards the Tradition on one hand, on the other, however, it is related to a searching of the universal way of expressing the drama of the human existence, literary adaptations of the biblical plot can serve both the polemic and the apologetic purposes in regards to the source. The matter is not in conciliative (i.e. imitative) repetitions of the canon, but refreshing revisions, situating themselves beyond its precise circle. These two ways of usage can be referred to two main - and somehow contradictory - tendencies of (post)modernity - unmasking and paraphrasing ${ }^{28}$, furthermore in both there is expressed its "heretical imperative".

\section{Unmasking apocrypha, or pseudo-gospel}

Apocrypha that belong to the unmasking line dominate in contemporary (and Western) culture ${ }^{29}$. What characterizes them is radical decontextualization of the original narration gained not by desacralization but by extreme antropomorfization, leading to unmasking of the Good News of the Christianity. The apocryphal themes used in them (i.e. known from ancient pseudo-canonical texts) appear in forms instrumentalized in the age of Enlightenment, serving often for a vulgarization of the message $e^{30}$. (Re)constructing so called institutional lies or intimate

\footnotetext{
${ }^{27}$ Further reading: P. Berger, Modernity as the Universalization of Heresy, [in:] IDEM, The Heretical Imperative. Contemporary Possibilities of Religious Affirmation, Garden City 1979, p. 1-31. The attribute "heretical" refers to the etymology of the Greek word "heresy" (i.e. choice).

${ }^{28}$ Cf. A. Bielik-Robson, Czy duchowość ponowoczesna..., p. 265-268.

${ }^{29}$ E. Drzewiecka, Ewangelia o końcu świata? O bułgarskich parafrazach biblijnych po 1989 roku, [in:] Kulturowe paradygmaty końca. Studia komparatystyczne, ed. J.C. KA£UŻNY, A. ŻYwioŁeK, Częstochowa 2013, p. 165-185; EADEM, Pseudo-Ewangelie Judasza, czyli o (po)nowoczesnych apokryfach bułgarskich, [in:] Slovanský svět: známý či neznámý?, ed. K. Kedron, M. PříHoda, Praha 2013, p. 73-82; EAdem, Koniec eschatologii? Poszukiwania modus existendi $w$ świetle (po)nowoczesnych apokryfów bułgarskich, SMer 14, 2014, p. 351-384 (DOI: 10.11649/sm.2014.017)

${ }^{30}$ For more cf.: E. DRZEWIECKA, Bluźnierstwo w kulturze popularnej. Wizerunki postaci biblijnych w wybranych powieściach bułgarskich XXI wieku, [in:] Tabu w oku szeroko otwartym, ed. N. DŁUGosz, Poznań 2012, p. 203-212.
} 
matters, especially regarding the character of Jesus, so revealing what (has been) hidden (concealed) either in political or private order, they refer to the etymology of the concept but also - as a paradox - they claim to define "revealed" truth.

As a consequence from canon's perspective they seem to be deformed above all in idea's plan. Jesus at best appears to be an unusual man and Christianity becomes a project which is either utopic, or initially mendacious ${ }^{31}$. The negative diagnosis of the actual state that comes together with this leads to establishing a pessimistic vision of the world as a whole ${ }^{32}$. Evangelic narration is not just a subject of criticism, but often also its metonymy. Analysis of the deep structures shows that most of texts can be inscribed into the Gnostic paradigm, and its so-called good news is completely destroyed, quite often in spite of the original intentions of their authors. Revealing the negative image of the world as a prison in which rules the eternal cycle of violence, rejecting the transcendental perspective, they conceal the tragic vision of an unsaveable life. So as a paradox "unmasking apocrypha" show that searching for successful conceptual frames in the reversed world of immanence can lead to the enslavement by a new fiction (i.e. metanarrative) and that - to the twisted affirmation of the just diagnosed evil. The emerging from them view of the unchangeable fate gains a therapeutic character as it gives sense to life, building the illusion that the essence of history is violence. In this way they actualize the meaning of the apocrypha as a sacred and condemned text. Criticizing the actual state, in the end they appear to be nihilistic. Uncovering (unmasking) what should not be, they illustrate at best the agatological experience according to Jozef Tischner, which is based on a good idea, but in practice as a difference with the axiological experience, it only keeps objecting ${ }^{33}$.

On the other hand, however, "unmasking apocrypha", having a "heretical" (in both, etymological and colloquial sense) attitude to the canon, not so much challenge the very legitimacy of its existence, but aspire to be its replacement, in fact they reveal a desire to find an axiological centre, even if it would be a negative one and

\footnotetext{
${ }^{31}$ As an ambiguously positive character Jesus gains the features of an enlightened teacher or a moral reformer (in Ognian Boiadziev's novel Седемте дни след Тайната вечеря (The Seven Days after the Last Supper)). Most often, however, he is a tragic character: as a victim of a manipulation (in Veselin Stoianov's novel Aymonсия на Тялото (The Autopsy of the Body) and in Stefan Tsanev's play Тайното евангелие на Йоан (The Secret Gospel of John) and in his novels Мравки и богове. Хроника на XX век (Ants and Gods. Chronicles of the XX Century) or a victim of his own weakness (in Christo Stoianov's novel Копелето. Евангелие от Юда (The Bastard, Gospel of Judas)).

${ }^{32}$ As the divine order becomes negated, the negative diagnosis of the actual state requires an explanation in the human order. Jesus's loss can have its reason not only in the successful politics of the enemy (according to Boiadziev) but also in the twisted nature of the disciples (according to Tsanev and Veselin Stoianov). In both cases, however, it leads to the general constatation that the world is fulfilled entirely by lies and violence. Of course, this kind of apocrypha may be seen as a product of the rules of the book market, an author's play which repeats some typical for the Western postmodern literature tricks in order to gain the audience's attention. But here I would like to stress the fact that even if that is the case, it also creates an important from the ideological point of view message. More below.

${ }^{33}$ J. Tischner, Myślenie według wartości, Kraków 1993, p. 516.
} 
would mean a contemplation of the structural evil. By faking the canon, they express in fact longing to the order. In the situation of the fall of the "metanarratives" only interpretations, either considered as own or imposed, offer a longed-for help ${ }^{34}$. That is why the apocrypha conventionally called by me "unmasking" not only uncover (unmask) a nihilistic vision of the world, but also impose it and in effect they become victims of the just unmasked total perspective but with a negative value.

The adopted in them biblical themes either in Judeo-Christian or (post)enlightenment form serve in fact their own discreditation. That is why they can be called parasitic works, which makes them similar to the texts of the so called Radical Enlightenment according to Charles Taylor ${ }^{35}$, i.e. a phenomenon which proclaimed the rejection of the old values but in fact expressed itself only by the negation of them. In this perspective "unmasking apocrypha" in a new way would express its original duality, i.e. its impossibility of functioning without the antithesis. According to Philip Rieff this strategy of (in)existence defines the dominating nowadays model of culture, called by him "culture of fiction"36. In this capture the texts of (post)modern culture, accusing the traditional models (i.e. the culture of fate and faith, equivalents of pagan and Judeo-Christian culture) of being sources of evil (at the same time applying exteriorization and later total annihilation to them), exist only through the negation, i.e. defining themselves in regards to the unmasked models of experience, they parasite on their "props".

But Rieff's notion of postmodernity is radically critical and claiming ${ }^{37}$. It seems to be too total and unambiguous. And yet, there is another perspective - the paraphrasing one, in which apocrypha appears to have sense-making potential, and not just destructive one. As Agata Bielik-Robson underlines, as far as the unmasking line of postmodernity is based on the form of pastiche, i.e. a form which acts as a parasite of the source, sterilizing it of its (as if illusive) sense $e^{38}$, and in this way it becomes kind of Rieff's text of the culture of fiction, the paraphrase - in accordance with its etymology - is rather a "transfer-next to" than "standing-in front", so it unites change and continuity ${ }^{39}$. Paraphrases of biblical themes can be not only an absolutely twisted (and seditious) repetition, or even an conciliative imitation, but also $a$ new reading as a remembrance through the creative embodiment.

\footnotetext{
${ }^{34}$ Cf. A. Zeidler-Janiszewska, „Druga moderna”. O jednej z prób uporzadkowania krajobrazu po postmodernizm, [in:] Sztuka wspótczesna i jej filozoficzne komentarze, ed. T. Kоsтүrкo, G. DziAMSKI, J. ZydorowiCZ, Poznań 2004, p. 111-121.

${ }^{35}$ Cf. Ch. Taylor, Sources of the Self..., p. 321-354.

${ }^{36}$ PH. Rieff, My Life among the Deathworks. Illustration of the Aesthetics of Authority, Charlottesville 2006, p. 1-44.

${ }^{37}$ Rieff's concept would fit in one of the two postmodern tendencies in Agata Bielik-Robson's capture, i.e. unmasking, cf.: A. Bielik-RoBson, Czy duchowość ponowoczesna..., p. 265-268.

${ }^{38}$ Bielik-Robson refers to "pastiche" in Fredric Jameson's capture and the "break of unmasking illusions" in Zygmunt Bauman's concept. Cf.: F. JAmESon, Postmodernism: The Cultural Logic of Late Capitalism, Durham 1991, p. 1-54; Z. Bauman, Postmodern Ethics, Cambridge 1993, p. 16-36.

${ }^{39}$ And that is why Bielik-Robson decides to replace the term parody with a more neutral and distinct, because of the prefix para- the concept of paraphrase. A. BIELik-RoBson, Czy duchowość ponowoczesna..., p. 268.
} 


\section{Paraphrasing apocrypha, or epiphany of sense}

Literary paraphrase can serve the actualization of the original narration through a new reading in a new situation. As a specific form of expression, secondary but also a dynamic one, it can become a source of refreshment and even renewal - of course in the pluralistic conditions of (post)modernity it would be a renewal in the conceptual framework of weak thought ${ }^{40}$. An illustration of a paraphrasing reading on the Bulgarian soil are two novels from the beginning of $21^{\text {st }}$ century: Filip Dimitrov's Светлина на човеии (Light of Man) (2003) and Teоdora Dimova's Марма, Мариам (Marma, Mariam) (2010). They avoid the traps of popular interpreting models, situating themselves in the horizon of positive (in this case: Christian) Good News and even actively proclaiming it ${ }^{41}$.

I will stop here on Dimova's novel as it unites the social issues developed so far by the author with the matter of religious belief that interests her at present ${ }^{42}$. It is a subtle but also a distinct testimony of the main character - a converted person; a woman, who having experienced the hardship of life, including the social and economic difficulties in Bulgaria after 1989, in situation of the broken family ties chooses a seclusion. She opens to God there; she also decides to tell over and over again the story of Jesus from Nazareth, reaching as a result fame among the thirsty for spiritual pasture Bulgarians. In effect the novel is a dynamic record of one of her stories. Evangelical paraphrase is enriched with a psychological element but even so it has a strictly Christian dimension in regards to both the plot and the message. All mysteries of faith and matters problematic from doctrine's point of view are discussed or presented only in conditional or questioning mood. Thanks to stressing on the personal experience and keeping the narration in constant suspension the risk of challenging the authority disappears. The story turns out to be an epiphanic act. Both the personage and the author take an evangelization mission through the word $^{43}$. The fact of interweaving of the two different time and

\footnotetext{
${ }^{40}$ However it has to be pointed out that Rieff rejects the weak thought as itself. He speaks against the "no" negotiated posture. „The Negotioned No". Ph. Rieff, op. cit., p. 137-138. Cf. M. LubańsKa, Postchrześcijaństwo i postjudaizm w teorii kultury Philipa Rieffa, SMer 8, 2008, p. 380.

${ }^{41}$ Regarding Dimitrov's novel: E. Drzewiecka, $(\mathrm{Od})$ nowa chrześcijańska? Apologia wedtug powieści Filipa Dimitrowa „Светлина на човеци”, PSł 2012, 1-2, p. 123-136.

${ }^{42}$ Dimova is a daughter of the famous Bulgarian writer Dimitar Dimov and an author of a dozen theatre plays and highly acclaimed novels: Емине (Emine) (2001), Майките (The Mothers) (2006), Адриана (Adriana) (2007). In the last years she converted to Orthodox faith, and the religious motives began to occur in her writings - Т. ДимовА, А. ГЕОргиЕвА, Човекът не може сам, без иърквата, да се справя с вярата си, Нови 6.05.2010, р. 26; Т. ДимовА, Т. Николов, Вярата предполага и изисква нашата свобода, ХК 2011, 10, p. 5-9. It needs to be added that Марма, Мариам won in 2010 the prestigious award „Христо Г. Данов“. I wrote about the novel also in: E. Drzewiecka, Ewangelia o końcu świata?...; EAdem, Metamorfozy Judasza....

${ }^{43}$ Compare author's statement regarding her conversion: Когато повярвах в Боговъпльщението, потресението ми беше огромно и смайващо, нямаше по какъв друг начин да реагирам освен чрез думите, просто пишех, защото не можех да не пиша. Винаги съм мислела, че това е единствената причина, която оправдава появата на една книга. (...) Много ми типсваше подобен роман в българската литература. Ако Марма, Мариам беше написан от някой друг,
} 
space plans, the biblical and the contemporary one, makes the Bulgarians of the beginning of $21^{\text {st }}$ century to be addressee.

The Good News is expressed in the truth of Jesus as a God who is present in life of every man, ready to cure him and accept in every situation. An illustration of his good will is the history of Judas. As the narrator persuades, all people are sinful and they usually do not know how to react during the meeting with God. Despite being saved and gifted with trust, the new disciple betrays, feeling envy and disappointment, so his fate is in harmony with the Orthodox message. His motivation is not reduced to the financial matters. The key to his act appears to be the struggle with the difficult experience of the Teacher's divinity. In this regard the meaningful scene is Peter's confession: "Thou art the Christ, the Son of the living God". (Mt 16,16 ; KJV Bible). At this moment Judas grabs his head and starts bitterly crying over his own fall. Man - it can be added the (post)modern one - cannot cope with the presence of God:

не беше по силите на човека да бъде с Него, Христе наш, иди си от нас, ние сме грешни човеци (it was not in man's strength to be with Him, our Christ, go away from us, we are sinful humans) (p. 139).

According to the Christian teachings the reasons for this state should be found in the consequences of the original sin, and the solution - in the salvific death of God's Son, bringing the spiritual gift of grace, i.e. the strength to endure in the face of the Creator. The drama of the human existence brings to mind Max Picard's ascertainment that "the distance between God and man is filled with flight" ${ }^{\text {" }}$. It appears that it has become an irrelevant feature of (post)modern culture. On the other hand, however, in regards to the lack of the traditional religious anchoring, to the constant necessity of making a worldview choice, the statement that this

ако го бях прочела преди време, мисля, че пгтят ми към храма щеше да бъде много по-къс. От друга страна, много добре знам, че един роман никога няма да оббрне човек във вярата, ако преди това не е бил привлечен към нея. Но по някакъв начин ще му помогне. Да, литературата винаги по тайнствен начин помага на отделния човек, влияе му, кара го да се придвижва по пбтя си. Аз съм убедена, че не можеш да повярваш, ако не видиш, че някой друг е повярвал. Затова и този императив, който непрестанно усещзаме в себе си - да свидетелстваме (When I believed in Incarnation of God my shock was big and astonishing, there was no other way for me to react except by words, I was just writing, because I could not stop writing. I have always thought that this is the only reason which justifies the appearance of a book. (...) I missed such a novel in Bulgarian literature very much. If Marma, Mariam was written by someone else, if I had read it some time ago, I think that my way to the Church would have been much shorter. On the other hand I know very well that a novel can never turn someone to the faith, if one has not been attracted to it. But in some way it will help him. Yes, literature always helps the given person in a secret way, it influences him, makes him walk his way. I am convinced that you cannot believe, unless you see that someone else has believed. That is why this imperative exists, which we constantly feel in ourselves - to testify). Quoted acc.: Т. ДимовА, Т. Николов, оp. cit., p. 6-7.

${ }^{44}$ M. PiCARD, Die Flucht vor Gott, Erlenbach-Zurich 1951, p. 17; post K. Dorosz, Zerwana więź, [in:] EADEM, Bóg i terror historii, Warszawa 2010, p. 179. 
space is full of possibilities brings also a positive message. In Dimova's novel it is expressed in the possibilities of making a radical life decision as the narrator did.

And the very matter of conversion - not only in the perspective of the story of the betrayer but also of the main character - is an interpreting key to the novel марма, Мариам, moreover not only the distance to God but also the time and place of the sacred history turn out to have the sense-making potential. According to the Church's teachings at the beginning there are tears of repentance and it is never too late for them. In this sense in Dimova's work Good News is addressed to the (post)modern man. Its patron though becomes not Judas - as it would result from the "unmasking apocrypha", but Unbelieving Thomas, an apostle who cried when he saw what he could not believe - Jesus Resurrected himself (comp. Io 20,24-29). In author's interpretation Jesus's words "Because thou hast seen me, thou hast believed: blessed are they that have not seen, and yet have believed" (Io $20,29)$ are a sign of the greatest hope - the hope given to the people today:

Тази Исусова последна благословия към всеки новопристъпил във вярата, която премахва вековете и времето, тази последна негова благословия, която всеки от нас лично получи заради неверника Тома, тази благословия, която рано или късно ни застига през живота ни като изумителен и незаслужен дар, като най-дълбокия печат от земното ни съществуване (This Jesus last blessing to every newcomer to the faith, which removes centuries and time, this last his blessing, which everyone of us personally received, because of the unbelieving Thomas, this blessing which sooner or later catches up with us with in life like an amazing and undeserved gift, like the deepest signature of our existence on earth) (p. 253).

The Good News is "alive" (situated hic et nunc) experience of the Savior. Unbelieving Thomas's fate brings the hope to the people today. Blessed are those who have believed, though have not seen, i.e. those who have "just" heard the story, so they have experienced a twofold mediated testimony.

Dimova's novel sets a refreshing paraphrase of the evangelical story. It is a Gospel of Salvation but also an Gospel of the end of the world, but the world of wide-spread (not only in Bulgarian culture) literary and thinking schemes, which - as previously presented apocrypha show - usually leads to the state of total nihilism and atrophy. Finally it appears to be an illustration of the positive potential embedded in the paraphrase in conditions of the Rieff's culture of fiction, i.e. in conditions of the unmasking (post)modernity.

And that is how the peculiar connection between te(le)logical sense of the Word as a Testimony and a Paraphrase as a repetition in a new context is revealed. Paraphrases of the biblical story can be an anamnesis with a little shift, an artistic embodiment (an incarnation), but a creative one. In postmodern conditions it requires a rejection of the metaphysical assumptions, a private language of reflection 
and acceptance of the multiple sense making languages ${ }^{45}$. In this place is revealed the potential of the individual act of creation, which is the work of art. According to Charles Taylor the worldview searching always is connected with the expression of identity. As a way to settling the horizon of senses he shows not a traditional metaphysics but authentic poetic experience ${ }^{46}$. This notion seems to correspond with the message of Dimova's novel; regarding the source of her story it is related to the sacred order sensu stricto, and hence it signalizes a presence of metaphysical assumptions, but it is the fact it is a record of the personal experience, the sacred history told in own words (Bulgarian verb преразказвам [re-narrate, paraphrase] fits perfectly here) that sets the novel in a postmodern plan, i.e. in the conditions of rejecting the ontology, where the sense-making horizon has not been already given (inherited), so it requires taking an individual decision/intervention.

The literary, author's paraphrases of sacred history appear to incarnate Taylor's ideal of the authentic expression, where authenticity keeps its ambivalence and is not just a "counter" creation, but also a self-definition in an open dialogue with another (meaning) ${ }^{47}$. Such a paraphrasing posture builds a personal horizon of sense in a conscious act of "creation" - as a being weaker than the universal structure of the myth or the religious belief, but opening to a new "attunement" (to the world) ${ }^{48}$. The postulated here "individual epiphany" is situated beyond ontology, because the sense is not searched in the hidden nature of things but in the axiological experience ${ }^{49}$. It, however, does not bring a constatation about the objective being (which due to the common rejection of evil often is identified with the total profanation), but becomes a source of purposefulness of the individual existence, all the more so as the dynamic dimensions of the human condition means that each time it is defined "just" its potential. As Taylor points out (but so does Rieff), the work of imagination has to complete the act of the world's creation. The key, however, is the way of seeing it. In the conditions of "unmasking" (post)modernity it is about an affirmative $\operatorname{look}^{50}$, i.e. correcting the "defiled" optics and getting rid

\footnotetext{
${ }^{45}$ A. Bielik-Robson, Czy duchowość ponowoczesna..., p. 268, 277-284. Cf.: EAdem, Romantyczne dopetnienie: komentarz do epifanii nowoczesnej Charlesa Taylora, [in:] EADEM, Inna nowoczesność..., p. 296-330.

${ }^{46}$ C. TAYLOR, The Ethics of Authenticity, Cambridge 2003; IDEM, Sources of the Self..., p. 419-494.

${ }^{47}$ IDEm, The Ethics of Authenticity..., p. 66-67.

${ }^{48}$ The word "attunement" is applied in this context by Charles Taylor. Cf.: C. TAYLOR, Sources of the Self....

${ }^{49}$ It seems that Peter Berger speaks in a similar way of participation in a higher order, when he considers as most adequate in (post)modern conditions (in regards to the existence of a "heretical imperative") the religious thinking of the inductive type. It relies on the turning towards one's own experience, though in religious tradition (understood as a collection of proofs regarding it). The approach is reflective, it keeps an empirical distance but at the same time it remains open to living the sacred. Cf.: P. BERGER, Religion: Experience, Tradition, Reflection, [in:] IDEM, The Heretical Imperative..., p. 31-60.

${ }^{50}$ C. TAYLOR, Sources of the Self..., p. 448-452.
} 
of the total and based on the ressentiment perspective ${ }^{51}$. Otherwise there is only a nihilistic worldview typical for the Gnostic model of thinking, which in fact betrays the positively valorized "heretical imperative". That is why the paraphrasing apocrypha can reveal the axiological perspective, hence enable a projective attitude to the world ${ }^{52}$. Introducing a small change (shift), correcting the optics, and at the same time manifesting an individual decision, it is an epiphany of the sense for the entity. As individual interpretation of the canon it becomes an evidence of the worldview research in the axiological order and not in a annihilating one.

In the field of hermeneutics each interpretation is an expression of some sense, even if it is a therapeutic fiction of the totality of evil. As a consequence (post)modern apocrypha is not just a matter of studies over the biblical (JudeoChristian) tradition in the Modern culture, but appears to be also a response to the "heretical imperative". As long as in paraphrasing option it illustrates a positive way to finding sense, in unmasking option it shows usually compensating - thus also sense-making - acceptance of (already unmasked) total perspective but with a converted value. From point of view of the history of ideas it develops a potential embedded in its ancient equivalent, i.e. hiding minority truths, in fact it reveals problems affecting the present man, which has a crypto-theological character. In existential dimension, however, only these apocrypha which incarnate the ideal of (philosophical) paraphrase, appear to execute the positive aspect of the worldview research. In this sense the means for discovering successful (i.e. satisfying the desire for a happy life) conceptual framework today, turn out to be only the paraphrasing apocrypha. Therefore, they appears to be the epiphany of sense par excellence. Although not all (post)modern apocrypha seems to be epiphanic, each of them is potentially sense-making and that is why the very meaning of them is that they stand as an authentic expression of will.

\begin{abstract}
The paper is devoted to the author's concept of modern apocrypha in the context of the two main tendencies of (Post)modernity: unmasking and paraphrasing. On the basis of the literary paraphrases of the Evangelical story, found in the Bulgarian (Post)Modern literary, there is shown a hermeneutic passage from "apocrypha as a literary mystification" ("literary apocrypha"), i.e. a concept often applied in literary studies, to "apocrypha as an epiphany of sense", i.e. a concept which can be useful in cultural studies and in history of ideas.

It is suggested that in the light of the postsecular thought, being an individual interpretation of the canon, the (Post)Modern apocrypha has a great epiphanic potential, which means that hiding minority truths, it reveals in fact some crucial, and crypto-theological, problems of the present. Drawing the axiological difference between "the unmasking apocrypha" (pseudo-gospel) and "the paraphrasing apocrypha" (epiphany of sense), the author claims that only the last one does actually
\end{abstract}

\footnotetext{
${ }^{51}$ M. Scheler, Ressentiment, ed. L.A. Coser, trans. W.W. Holdheim. New York 1972. Compare the Eric Voegelin's notion of total "pneumopathology" in: E. Voegelin, Science Politics, and Gnosticism, Chicago 1968. Cf. also: K. Donosz, Bóg i terror historii..., p. 11-14, 21-22.

${ }^{52}$ J. Tischner, op. cit., p. 516.
} 
incarnate Charles Taylor's ideal of the authentic (and poetic) expression (of will), which helps in establishing an individual sense-making horizon as a positive response to the "heretical imperative" of (Post)Modernity.

Keywords: apocrypha, modernity, postmodernity, Bible, Bulgarian literature.

Ewelina Drzewiecka

Institute of Slavic Studies

Polish Academy of Sciences

ewelina.drzewiecka@gmail.com 